\title{
Conditioning factors to market fruits and vegetables from family farms to supermarket supply chains
}

\section{Leandro Gomes de Oliveira ${ }^{1^{*}}$ (]) Mário Otávio Batalha ${ }^{2}$ (1)}

${ }^{1}$ Instituto Federal do Amapá (IFAP), 68980-000, Oiapoque, AP, Brasil. E-mail: leandro.oliveira@ifap.edu.br. "Corresponding author. ${ }^{2}$ Programa de Pós-graduação em Engenharia de Produção (PPGEP), Universidade Federal de São Carlos (UFSCar), São Carlos, SP, Brasil.

ABSTRACT: Globally, increasing number of fruits and vegetables are being consumed to maintain healthy eating habits. Family farming plays a crucial role in fruits and vegetables production; products are marketed in supply chains, which are increasingly demanding, diversified, and complex. Participation of the family farms in each of these supply chains is subject to their ability to meet the increasingly strict participation criteria. In this context, this study identified the main factors that affect the participation of the family farmers in the supermarket supply chains for fresh fruits and vegetables. A systematic literature review was conducted, covering the period from 2005 to 2019. Results indicated eleven variables that affect the participation of the fruits and vegetables family farms in the supermarket supply chains. These variables were grouped in an analytical framework, which comprised four factors: characteristics of the producer, characteristics of the farm, institutional aspects, and available infrastructure. This framework is useful for the development and implementation of the public and private policies for successful participation of fruits and vegetables family farmers in supermarket supply chains.

Key words: supermarket, producer characteristic, property, institutional environment, production infrastructure.

Fatores condicionantes à comercialização de frutas, legumes e verduras da agricultura familiar em cadeias de suprimentos de supermercados

RESUMO: Preocupações ambientais e a busca por uma alimentação saudável têm levado ao aumento mundial de consumo de frutas, legumes e verduras. A agricultura familiar é um segmento muito importante na produção de frutas, legumes e verduras, sendo os seus produtos comercializados em cadeias de suprimentos crescentemente mais exigentes, complexas e diversificadas. A participação de produtores familiares em cada uma destas cadeias de suprimentos está submetida a capacidade deles atenderem critérios de inserção cada vez mais estritos.As cadeias de suprimentos de frutas, legumes e verduras que abastecem os supermercados não fogem a esta situação.Neste contexto, este artigo identificou os principais fatores que condicionam a inserção dos agricultores familiares nas cadeias de suprimentos de frutas, legumes e verduras dos supermercados.Para tanto, foi realizada uma revisão sistemática da literatura num periodo compreendido entre 2005 e 2019. Os resultados encontrados mostraram que existem onze variáveis que condicionam a inserção da agricultura familiar em cadeias supermercadistas de frutas, legumes e verduras. Estas variáveis foram agrupadas em um framework analítico composto por quatro fatores: características do produtor e da propriedade, aspectos institucionais e infraestrutura. Este framework é útil ao desenvolvimento e implementação de políticas públicas e privadas voltadas à inserção exitosa da produção de frutas, legumes e verduras de agricultores familiares nas cadeias de suprimentos de supermercados.

Palavras chave: supermercados, características do produtor, propriedade, infraestrutura de produção, ambiente institucional.

\section{INTRODUCTION}

The global consumption of fruits and vegetables has increased over the years. One of the main reasons is a greater awareness regarding the benefits of a healthy diet (BERNAL et al. 2018) and environmental concerns (RIBEIRO et al., 2017). Within this context, supermarkets have become increasingly important points of sale for fruits and vegetables (NEVEN et al., 2009).
The great transformation of food chains expanded the supermarket networks on a large scale, being referred as the "supermarket revolution" (ANDERSSON et al., 2015). From the early 1990s, supermarkets have been increasing their market share and accountability for selling various durable and non-durable products such as fruits and vegetables (SAHARA et al., 2015).

Globally, family farming constitutes a major portion of the rural enterprises, regardless of the 
development level (GRAEUB et al., 2016). Although, family farming is crucial for fruits and vegetables production, they can only sell to the supermarkets if they meet the minimum standards set by the retailers.

Several studies, worldwide, have been conducted to analyze the enabling processes and conditions for family farmers' participation in the supermarket chains (BLANC et al., 2009; SAHARA et al., 2015; MASPAITELLA et al., 2017). However, the literature struggles to find consensus on positive conditioning factors required for family farmers' participation. Furthermore, these studies incorporated only one or few variables in their analyses, neglecting other equally important factors. This study; however, identified and analyzed all the relevant variables, enabling the entry of the family farmers in the supermarket supply chains.

Successful entry of the farms in the supermarket chains depends on multiple factors. Thus, multifaceted solutions are required. This study proposed a theoretical framework incorporating this concept, which serves as an analytical tool to provide theoretical and empirical support for establishing public and private policies, enabling larger participation of the family farms in the supermarket supply chains.

\section{MATERIALS AND METHODS}

A systematic literature review was conducted to explore the following research question. "What are the conditioning factors for family farmers to supply fruits and vegetables in supermarket chains?" Literature was extracted using the Web of Science, Scopus, and SciELO databases. Compared with the other databases, SciELO provided the lowest number of articles, summaries, and citations but was still used because it contained relevant Brazilian studies (BUCHINGER et al., 2014). The database searches were based on a combination of the following words and expressions: (access or participation) AND (smallholder or "small farm" or "family farm") AND (supermarket). Four filters were used to select the articles. The first filter specified the product group using the words "horticulture", "fruits," and "vegetables". The second specified the fields of Social and Agricultural Sciences. The third restricted the documents to articles, reviews, book chapters, and conference articles. Finally, only the English and Portuguese languages were selected.

The procedures led to the selection of 36 articles from the Web of Science, 18 from Scopus, and none from SciELO, which demonstrated the scarcity of Brazilian studies on the subject. Subsequently, inclusion and exclusion criteria were determined to exclude articles that did not meet the study objectives (Table 1).These criteria were designed through a prior reading of the five best-ranked articles (score) defined by the START software (Laboratory of Software Engineering Research, 2020).

Twelve studies were selected after going through the introduction and conclusion of these articles. Subsequently, a reverse search was conducted in the references, identifying studies undetected in the first search. This procedure resulted in 21 studies.

The enabling variables for family farmers' participation in supermarket supply chains, identified from the selected articles, were grouped into four constructs, which were composed of the nomenclature and the same classification logic used by the related authors of similar studies.

\section{RESULTS AND DISCUSSION}

The systematic literature identified the variables facilitating family farmers' participation in the supermarket supply chains. The articles that provided the definitions and supported the theoretical formulation for this study are presented in table 2 . Each of the variable used is briefly described below.

Age

The literature widely addresses age as an enabling factor in family farmers' participation in the supermarket supply chains, though in conclusions they remain insignificant. Some studies stated that younger farmers are more willing to participate in the supermarket supply chains (SAHARA et al., 2015; MASPAITELLA et al., 2017), while others (RAO et al., 2012) concluded that older farmers are more suitable.

According to SAHARAet al. (2015), younger family farmers are more entrepreneurial, take quicker decisions and are willing to use newer technologies to analyze market conditions, thereby creating a suitable environment to negotiate with the supermarkets. Alternatively, MASPAITELLA et al. (2017) and RAO et al. (2012) concluded that older farmers have more experience and knowledge, in addition to a reputation that enhances their relationship with the supermarkets.

\section{Education}

The farmer's education may directly influence his or her ability to participate in the supermarket supply chains (BLANDON et al. 2009). The reason, in addition to being more confident and innovative, is higher farmers education, which is more willing to undertake necessary investments, meeting 
Table 1 - Inclusion and exclusion criteria for the systematic literature review.

\begin{tabular}{lc}
\hline & \\
\hline The study does not focus on the supermarket & EXCLUDE \\
The study does not focus on the family farms & EXCLUDE \\
$\begin{array}{l}\text { Mentions the criteria of participation in the supermarket chain and } \\
\text { the correlated conditioning factors }\end{array}$ & INCLUDE \\
Unavailable for download & EXCLUDE
\end{tabular}

Source: Designed by the authors.

the supermarket standards (SAHARA et al., 2015).

MASPAITELLA et al. (2017) identified a positive correlation between education and the participation of farmers in the supermarkets. Educated farmers possess better managerial abilities, which are important for negotiating with the supermarkets, in addition to a better understanding of the fruits and vegetables production processes.

\section{Farm size}

The farm size has a significant influence on the farmers' participation in the supermarkets, since

Table 2 - Selected articles.

\begin{tabular}{|c|c|c|c|}
\hline Author (s) & Year & Journal & $\begin{array}{c}\text { Sample } \\
\text { (farmers) }\end{array}$ \\
\hline HERNÁNDEZ et al. (2007) & 2007 & American economics & 600 \\
\hline MYIATA et al. (2009) & 2009 & World development & 162 \\
\hline NEVEN et al. (2009) & 2009 & World development & 166 \\
\hline BLANDON et al. (2009) & 2009 & Journal of international development & 32 \\
\hline OUMA et al. (2010) & 2010 & Agricultural economics & 100 \\
\hline MARKELOVA \& MWANGI (2010) & 2010 & Review of Policy Research & Not mentioned \\
\hline RAO \& QAIM (2011) & 2011 & World development & 402 \\
\hline BRANDÃO (2011) & 2011 & PhD Thesis & \\
\hline RAO et al. (2012) & 2012 & American journal of agricultural economics & 402 \\
\hline ISMAIL et al. (2013) & 2013 & $\begin{array}{c}\text { Journal of agricultural economics and } \\
\text { development }\end{array}$ & 60 \\
\hline MATSANE \& OYEKALE (2014) & 2014 & Mediterranean journal of social sciences & 47 \\
\hline ANDERSSON et al. (2015) & 2015 & American journal of agricultural economics & 402 \\
\hline HERNANDÉZ et al. (2015) & 2015 & Bulletin of Indonesian economic studies & 600 \\
\hline SAHARA et al. (2015) & 2015 & Bulletin of Indonesian economic studies & 60 \\
\hline BRANDÃO \& ARBAGE (2016) & 2016 & Rural Extension & Not mentioned \\
\hline SLAMET et al. (2015) & 2017 & Agriculture & 137 \\
\hline MASPAITELLA et al. (2017) & 2017 & $\begin{array}{c}\text { International food and agribusiness management } \\
\text { review }\end{array}$ & 126 \\
\hline OCHIENG et al. (2018) & 2018 & Journal of agricultural education and extension & 300 \\
\hline ELDER (2019) & 2019 & Agriculture and human values & 110 \\
\hline DLAMINI- et al. (2019) & 2019 & $\begin{array}{l}\text { African journal of science, technology, } \\
\text { innovation and development }\end{array}$ & 170 \\
\hline MWANGI \& CREWETT (2019) & 2019 & Agricultural water management & 176 \\
\hline
\end{tabular}

Source: Designed by the authors. 
the size is related to the required production level for supplying (NEVEN et al., 2009; ISMAIL et al., 2013; BRANDÃO \& ARBAGE, 2016).

\section{Location}

The farm location may be an obstacle for family farmers to deliver their produce to the supermarkets (SAHARA et al., 2015).The farther the farm from the supermarket, the higher the transportation costs and thus, lower the margins.

MYIATA et al. (2009) concluded that the shorter the distance between the farm and the delivery point, the higher is the probability of becoming a supermarket supplier. HERNÁNDEZ et al. (2007) reported a negative correlation between the distance of the farm from the supermarket and participation, indicating that supermarket managers favor farmers who are located closer to the highways. BRANDÃO (2011) studied the governance structure of the fruits and vegetables supply chains in five micro-regions of the state of Rio Grande do Sul, Brazil, and observed that the farms were located less than $10 \mathrm{~km}$ away from the delivery points.

\section{Access to the farm}

The fragility and perishability of fruits and vegetables cause product quality to depend on the transportation conditions (DLAMINI-MAZIBUKO et al., 2019). Poor road quality may prevent family farmers from supplying supermarkets, forcing them to sell their products in less profitable and more risky markets (ANDERSSON et al. 2015).ISMAIL et al. (2013) and DLAMINI-MAZIBOKU et al. (2019) analyzed the influence of road conditions on the supply of fruits and vegetables by family farmers to the supermarkets. The authors concluded that $44.2 \%$ of the interviewed farmers identified poor road conditions as the principal obstacle in transporting fruits and vegetables to the supermarkets.

\section{The packing and storage}

The choice and use from a large range of packages and storage equipment are essential for supplying agricultural produce (MATSANE \& OYEKALE, 2014).SAHARA et al. (2015) concluded that the supermarket chains pay better for highquality, evenly shaped, and colored products stored in plastic bags or boxes.

SAHARA et al. (2015), SLAMET et al. (2017), and NEVEN et al. (2009)opined that family farmers who supply to the supermarkets must use packages that provide better preservation, in addition to owning storage, packaging, and distribution infrastructure. BRANDÃO (2011) stated that one of the retailer chains demanded plastic packages from farmers, attempting to reduce contamination.

\section{Transport}

Transport plays a significant role in the supermarket supply chains and is an important competitive variable for family farmers. The perishability attributes demand quality-preserving modes of transport. The vehicle of choice depends on the infrastructure and the farmer's purchasing power, in addition to the product type, the production rate, and the frequency of delivery (OUMA et al., 2010).

RAO and QAIM(2011), andANDERSSON et al. (2015) showed that family farmers who own vehicles probably supply supermarkets better. Similarly, HERNÁNDEZ et al. (2007) concluded that family farmers who own vehicles have a $30.5 \%$ better probability of supplying the supermarkets, compared with those who do not own one.

\section{Information exchange systems}

Family farmers who work in the fresh fruits and vegetables supply chains face the increasing demand of the modern supply chains regarding the flow of information among the agents. Thus, mobile phones and other communication services are vital for family farmers (SAHARA et al., 2015; SLAMET et al., 2017; DLAMINI-MAZIBUKO et al.,2019).

\section{Irrigation systems}

Irrigation systems are important for agricultural production, since they increase the quality, mitigate climate and sanitary risks, increase the planning ability and decrease production seasonality. They also lower costs and increase production rates, which favor the entry of family farms in the supermarket supply chains (BLANDON et al., 2009; RAO \& QAIM, 2011; RAO et al., 2012; MWANGI \& CREWETT, 2019).

$$
\text { HERNÁNDEZ et al. (2007), }
$$

HERNANDÉZ et al. (2015), NEVEN et al. (2009), and ANDERSSON et al. (2015) specified a positive correlation between irrigation and supply to supermarket chains. NEVEN et al. (2009) showed that drip irrigation increased the probability of the family farmers to participate in the supermarket supply chains by $46 \%$, indicating that irrigation is an important factor for farmers who intend to supply to the supermarkets.

\section{Collective organizations}

Participation in collective organizations, such as associations and cooperatives allows family 
farmers to reduce transaction and input costs and have better access to market information, services, and technical support (OCHIENG et al., 2018). Furthermore, collective companies of production and sales overcome barriers arising from markets that demand larger production rates. The scale provided by these organizations increases the bargaining power of the farmers, enabling them to compete against large farmers when it comes to more demanding supply chains such as supermarkets (MARKELOVA\& MWANGI, 2010; MASPAITELLA et al., 2017; ISMAIL et al., 2013; ELDER, 2019). Furthermore, it is worth noting that collective organizations favor the establishment of short supply chains, directly connecting family farmers to markets and eliminating intermediaries (MARKELOVA \& MWANGI, 2010).

\section{Access to rural extension services}

By offering technical support, public and private rural extension services enable farmers to adopt new management practices, thereby making them capable, providing a good quality product, meet supplier demands, and increasing their competitiveness (MASPAITELLA et al., 2017).

MATSANE and OYEKALE (2014), BRANDÃO \& ARBAGE (2016), and DLAMINIMAZIBUKO et al. (2019) pointed out that access to the rural extension services is a determining factor in supplying fruits and vegetables to supermarkets. The technical support offered by extension services proved to be crucial for farmers to access new knowledge and learn abilities in management and more efficient production processes.

The variables discussed so far were brought together through a theoretical framework (Figure 1), defining the principal positive or negative conditioning factors for the family farmers to participate in the fruits and vegetables supermarket chains.

Understanding these factors and their behavior is important for the family farmers who seek to integrate themselves into the fruits and vegetables supermarket supply chains. They are also essential for the supermarkets that negotiate with the family farmers. The supermarkets can quickly gauge which

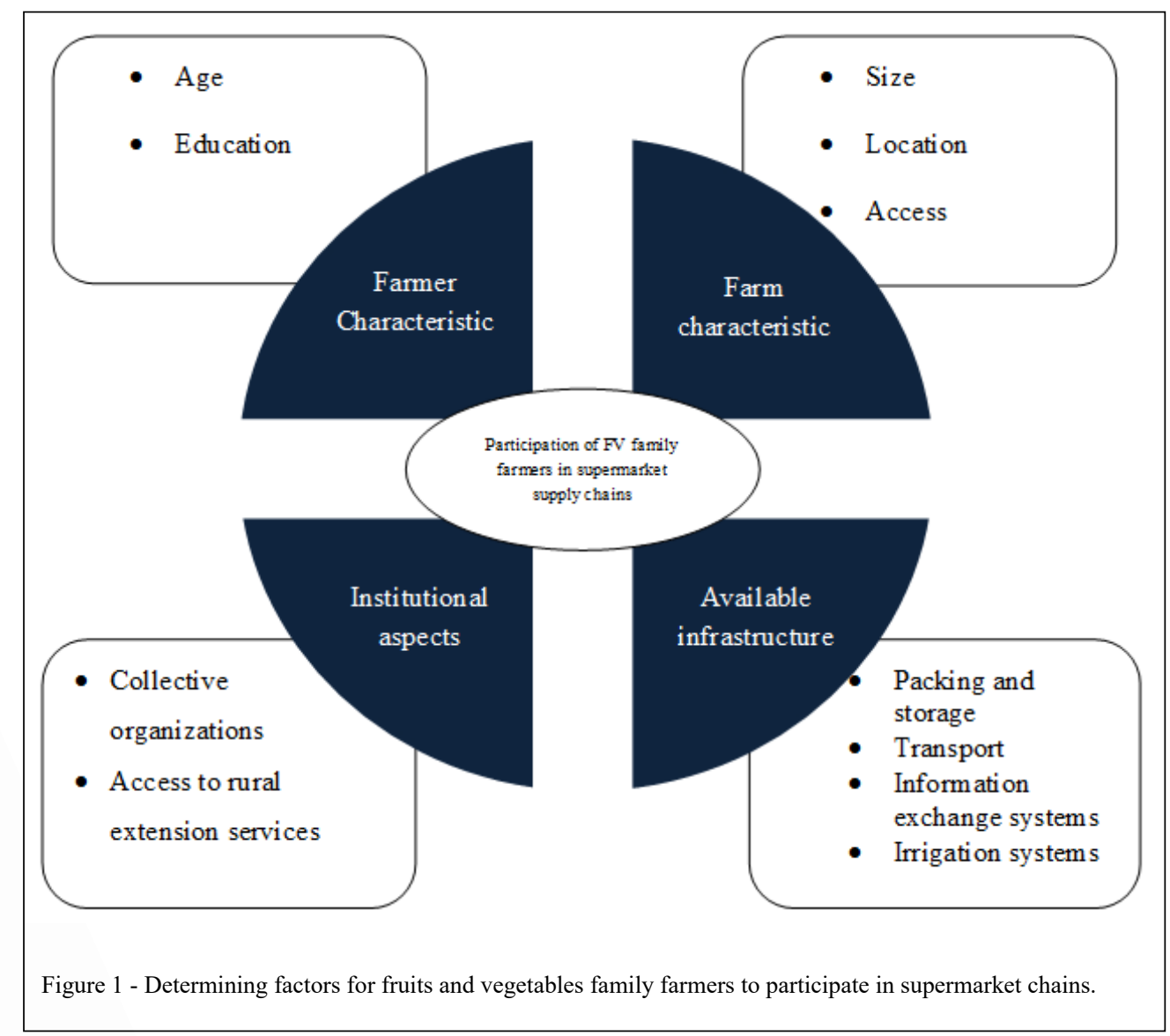

Ciência Rural, v.51, n.4, 2021. 
factors are present in the farmers to build an effective and efficient supply chain relation.

\section{CONCLUSION}

This article identify and assimilate the conditioning factors for participating the family farmers in the fruits and vegetables supermarket supply chains by developing an analytical framework, which allows family farmers to assess the main obstacles in selling their products to the supermarkets. The literature review led to the conclusion that the characteristics of the farmer and farm, the available infrastructure, and institutional aspects compose a set of variables that significantly affect the capacity of the family farmers to sell their products to the supermarkets.

It is worth mentioning that separately, these factors are unable to explain the higher or lower participation of fruits and vegetables family farmers in the supermarket supply chains. Thus, results reported in this study have the academic merit of bringing together, in an analytical framework, the enabling and limiting factors in family famers' participation in fruits and vegetables supply chains. Therefore, the entry of the family farmers into the supermarket supply chains does not only depend on the farmer and farm characteristics but also from the institutional aspects and the available infrastructure, to secure the conditions demanded by the buyers. The inevitable challenges for the family farmers to meet these requirements require the public and private policies that are demanded by supermarket supply chains.

We suggest that further research to empirically validate the theoretical proposition of this article. Since every study identified and analyzed in this research was developed abroad, it is important to validate these results considering the various regions in Brazil. Quantitative research on the family farmers allow us to validate and complement the theoretical constructs proposed in this study. The absence of Brazilian study puts forth an important limitation of this study and corroborates the importance of this article and how it fills the gap in the related Brazilian literature.

\section{ACKNOWLEDGMENTS}

This study was financed in part by the Coordenação de Aperfeiçoamento de Pessoal de Nível Superior - Brasil (CAPES) - Finance Code 001" and the authors thank the Universidade Federal de São Carlos (UFSCar) for providing with laboratories and to the Grupo de Estudos e Pesquisas Agroindustriais (GEPAI) of the Department of Production Engineering of the UFSCar for the development of technologies and knowledge for family farms.

\section{DECLARATION OF CONFLICT OF INTERESTS}

The authors declare no conflict of interest. The founding sponsors had no role in the design of the study; in the collection, analysis, or interpretation of data; in the writing of the manuscript, and in the decision to publish the results.

\section{AUTHOR CONTRIBUTION} writing this study.

All authors contributed equally to designing and

\section{REFERENCES}

ANDERSSON, C. I. M.; et al. Following up on smallholder farmers and supermarkets in Kenya. American journal of agricultural economics, v.97, n.4, p.1-20, 2015. Available from: <http:// ajae.oxfordjournals.org/content/early/2015/02/20/ajae.aav006>. Accessed: Jul. 28, 2020. doi: 10.1093/ajae/aav006.

BERNAL, R. T. I.; et al. Método de projeção de indicadores das metas do Plano de Ações Estratégicas para o Enfrentamento das Doenças Crônicas não Transmissíveis no Brasil segundo capitais dos estados e Distrito Federal. Epidemiologia e serviços da saúde, v.25, n.3, p.455-466, 2018. Available from: <http:// www.scielo.br/pdf/ress/v25n3/2237-9622-ress-25-03-00455. pdf $>$. Accessed: May, 1, 2019. doi: 10.5123/S167949742016000300002.

BLANDON, J. et al. Small-scale farmer participation in new agri-food supply chains: case of the supermarket supply chain for fruit and vegetables in Honduras. Journal of international development, v.21, p.971-984, 2009. Available from: <http:// onlinelibrary.wiley.com/doi/10.1002/jid.1490/full>. Accessed: Sep. 4, 2019. doi: 10.1002/jid.1490.

BRANDÃO, J. B. A gestão da cadeia de suprimentos das redes regionais de varejo de frutas, legumes e verduras no Rio Grande do Sul. 2011. 209 f. Thesis (PhD in Rural Extension)-Postgraduate Course in Rural Extension, Federal University of Santa Maria. Available from: < https://periodicos.ufsm.br/extensaorural/article/ view/18489>. Accessed: Jul. 19, 2020.

BRANDÃO, J. B.; ARBAGE, A. P. A gestão da cadeia de suprimentos das redes de varejo de frutas, legumes e verduras no Rio Grande do Sul: um estudo multicaso. Extensão rural, v.23, n.3, p.51-68, 2016. Available from: <https://periodicos.ufsm.br/ extensaorural/article/view/18489/pdf>. Accessed: Sep. 16, 2020. doi: $10.5902 / 2318179618489$.

BUCHINGER, D. Mecanismos de busca acadêmica: uma análise quantitativa. Revista brasileira de computação aplicada, v.6, n.1, p.108-120, 2014. Available from: <http://dx.doi.org/10.5335/ rbca.2014.3452>. Accessed: Aug. 21, 2019. doi: 10.5335/ rbca.2014.3452.

DLAMINI-MAZIBUKO, B. P.; et al. Factors affecting the choice of marketing outlet selection strategies by smallholder farmers in Swaziland. African journal of science, technology, innovation and development, v.11, n.5, p.569-577, 2019. Available from: <https://www.tandfonline.com/doi/full/10.10 80/20421338.2018.1554323>. Accessed: Feb. 28, 2020. doi: 10.1080/20421338.2018.1554323. 
ELDER, S. D. The impact of supermarket supply governance on smallholder cooperatives; the case of Walmart in Nicaragua. Agriculture and human values, v.36, p.213-224, 2019. Available from: $<$ https://link.springer.com/article/10.1007/s10460-019-099118>. Accessed: Jul. 15, 2020. doi: 10.1007/s10460-019-09911-8.

FALAGAS, M. E.; et al. Comparison of PubMed, Scopus, Web of Science, and Google Scholar: strengths and weaknesses. The FASEB journal, v.22, n.2, p.338-342, 2008. Available from: $<$ https://www.ncbi.nlm.nih.gov/pubmed/17884971>. Accessed: Jun. 1, 2019. doi: 10.1096/fj.07-9492LSF.

GRAEUB, B. E.; et al. The state of family farms in the world. World development, v.87, p.1-15, 2016. Available from: $<$ https://www. sciencedirect.com/science/article/pii/S0305750X15001217>. Accessed: Nov. 14, 2019. doi: 10.1016/j.worlddev.2015.05.012.

HERNÁNDEZ, R.; et al. Supermarkets, wholesalers, and tomato growers in Guatemala. Agricultural economics, v.36, p.281-290, 2007. Available from: $<$ http://onlinelibrary.wiley.com/doi/10.1111/ j.1574-0862.2007.00206.x/abstract>. Accessed: Dec. 18, 2019. doi: 10.1111/j.1574-0862.2007.00206.x.

HERNANDÉZ, R.; et al. Tomato Farmers and Modernising Value Chains in Indonesia. Bulletin of Indonesian economic studies, v.51, n.3, p.425-444, 2015. Available from: <http:// www.tandfonline.com/doi/abs/10.1080/00074918.2015.110 4649? journalCode $=$ cbie20 $>$. Accessed: Jan. 24, 2020. doi: 10.1080/00074918.2015.1104649.

ISMAIL, M.; et al. Factors influencing the choice of supermarket channel by smallholder vegetable farmer suppliers in Nairobi and Kiambu counties, Kenya. Journal of agricultural economics and development, v.2, n.9, p.333-344, 2013. Available from: $<$ https://ir-library.ku.ac.ke/handle/123456789/12608>. Accessed: Aug. 21, 2020

LABORATÓRIO DE PESQUISA EM ENGENHARIA DE SOFTWARE. Start. Available from: <http://lapes.dc.ufscar.br/ tools/start_tool>. Accessed: Aug. 12, 2020.

MARKELOVA, H.; MWANGI, E. Collective action for smallholder Market Access: Evidence and Implications for Africa. Review of policy research: The politics and policy of science and technology, v.27, n.5, p.621-640, 2010. Available from: <http:// onlinelibrary.wiley.com/doi/10.1111/j.1541-1338.2010.00462.x/ abstract $>$. Accessed: Dec. 19, 2019. doi: 10.1111/j.15411338.2010.00462.x.

MASPAITELLA, M.; et al. Towards high value markets: a case study of smallholder vegetable in Indonesia. International food and agribusiness management review, v.21, n.1, p.73-88, 2017. Available from: <https://www.wageningenacademic.com/doi/ abs/10.22434/IFAMR2017.0011>. Accessed: Jul. 15, 2019. doi: 10.22434/IFAMR2017.0011.

MATSANE, S. H.; OYEKALE, A. S. Factors affecting marketing of vegetables among small-scale farmers in Mahikeng local municipality, North West province, South Africa. Mediterranean journal of social sciences, v.5, n.20, p.390-397, 2014. Available from: <https://pdfs.semanticscholar.org/61ac/40db243479c47e 7965065cb70aab298d7966.pdf $>$. Accessed: Apr. 1, 2020. doi: 10.5901/mjss.2014.v5n20p390.

MEHO, L. I.; YANG, K. Impact of data sources on Citation Counts and Rankings of LIS Faculty: Web of Science Versus Scopus and
Google Scholar. Journal of the American society for information science and technology, v.58, n.13, p.2105-2125, 2007. Available from: $\quad<$ http://onlinelibrary.wiley.com/doi/10.1002/asi.20677/ abstract>. Accessed: Aug. 15, 2019. doi: 10.1002/asi.20677.

MWANGI, J. K.; CREWETT, W. The impact of irrigation on small scale African indigenous vegetable grower's market access in peri-urban Kenya. Agricultural water management, v.212, p.295-305, 2019. Available from: < https://www.sciencedirect.com/ science/article/abs/pii/S0378377418309168>. Accessed: Nov. 10, 2019. doi: 10.1016/j.agwat.2018.06.036.

MYIATA, S.; et al. Impact of contract farming on income: linking small farmers, packers, and supermarkets in China. World development, v.37, n.11, p.1781-1790, 2009. Available from: <https://www.sciencedirect.com/science/article/abs/pii/ S0305750X09001387>. Accessed: Jul. 19, 2018. doi: 10.1016/j. worlddev.2008.08.025.

NEVEN, D.; et al. Kenyan Supermarkets, Emerging MiddleClass Horticultural Farmers, and Employment Impacts on the Rural Poor. World development, v.37, n.11, p.1802-1811, 2009. Available from: $<$ http://www.sciencedirect.com/science/article/pii/ S0305750X09001405>. Accessed: Oct. 2, 2019. doi: 10.1016/j. worlddev.2008.08.026.

OCHIENG, J.; et al. Strengthening collective action to improve marketing performance: evidence from farmer groups in Central Africa. Journal of agricultural education and extension, v.24, n.2, p.169-189, 2018. Available from: <https://www.tandfonline.com/ doi/abs/10.1080/1389224X.2018.1432493? journalCode $=$ raee20 $>$. Accessed: Jun. 14, 2020. doi: 10.1080/1389224X.2018.1432493.

OLIVEIRA, L. G.; et al. Comparative assessment of the food purchase program and the national school feeding program's impact in Ubá, Minas Gerais, Brazil. Ciência rural, v.47, n.1, p.16, 2017. Available from: <http://www.scielo.br/pdf/cr/v47n1/16784596-cr-47-01-20160395.pdf $>$. Accessed: May, 5, 2019. doi: $10.1590 / 0103-8478 \mathrm{cr} 20160395$.

OUMA, E.; et al. Determinants of smallholder farmers' participation in banana markets in Central Africa: the role of transactions costs. Agricultural economics, v.41, p.111-122, 2010. Available from: <https://onlinelibrary.wiley.com/doi/abs/1 0.1111/j.1574-0862.2009.00429.x>. Accessed: Sep. 2, 2020. doi: 10.1111/j.1574-0862.2009.00429.x.

RAO, E. J.O.; QAIM, M. Supermarkets, Farm Household Income, and Poverty: Insights from Kenya. World development, v.39, n.5, p.784-796, 2011. Available from: <http://www.sciencedirect. com/science/article/pii/S0305750X10001695>. Accessed: Feb. 23, 2020. doi: 10.1016/j.worlddev.2010.09.005.

RAO, E. J. O.; et al. Farmer participation in supermarket channels, production technology, and efficiency: the case of vegetables in Kenya. American journal of agricultural economics, v.94, n.4, p.891-912, 2012. Available from: <https://academic.oup.com/ ajae/article-abstract/94/4/891/93138/Farmer-Participation-inSupermarket-Channels?redirectedFrom $=$ fulltext $>$. Accessed: Feb. 25, 2020. doi: 10.1093/ajae/aas024.

RIBEIRO, H.; JAIME, P. C.; VENTURA, D. Alimentação saudável e sustentabilidade. Estudos avançados, v.31, n.89, p.185-198, 2017. Available from: <https:/www.scielo.br/scielo. php? script $=$ sci arttext\&pid $=$ S0103-40142017000100185>. Accessed: Jan. $2 \overline{8}, 2020$. doi: 10.1590/s0103-40142017.31890016. 
SAHARA, S. A.; et al. Determinants and effects of small chilli farmers' participation in supermarket channels in Indonesia. Bulletin of Indonesian economic studies, v.51, n.3, p.445-460, 2015. Available from: <http://www.tandfonline.com/doi/abs/10. 1080/00074918.2015.1110851? journalCode $=$ cbie20 $>$. Accessed: Nov. 12, 2019. doi: 10.1080/00074918.2015.1110851.
SLAMET, A. S.; et al., Small-scale vegetable farmers' participation in modern retail market channels in Indonesia: the determinants of and effects on their income. Agriculture, v.7, n.11, p.1-16, 2017. Available from: <https://agris.fao.org/agris-search/search. do? recordID=US201900385492>. Accessed: Mar. 7, 2020. doi: 10.3390/agriculture7020011. 